\title{
Microplastics in Aquatic Environments: Recent Advances in Separation Techniques
}

\author{
Fahimeh Hooriabad Saboor ${ }^{1 *}$, Samaneh Hadian-Ghazvini², Mohammad Torkashvand ${ }^{3}$ \\ 1 Chemical Engineering Department, University of Mohaghegh Ardabili, 56199-11367 Ardabil, Iran \\ ${ }^{2}$ Institute of Biochemistry and Biophysics, University of Tehran, 1417614411 Tehran, P.O.B. 13145-1384, Iran \\ ${ }^{3}$ Fouman Faculty of Engineering, College of Engineering, University of Tehran, 4358139115 Tehran, Iran \\ * Corresponding author, e-mail: f.saboor@uma.ac.ir
}

Received: 13 July 2021, Accepted: 18 November 2021, Published online: 03 February 2022

\begin{abstract}
Separation and removal of microplastic pollution from aquatic environments as a global environmental issue is classified as one of the major concerns in both water and wastewater treatment plants. Microplastics as polymeric particles less than $5 \mathrm{~mm}$ in at least one dimension are found with different shapes, chemical compositions, and sizes in soil, water, and sediments. Conventional treatment methods for organic separation have shown high removal efficiency for microplastics, while the separation of small microplastic particles, mainly less than $100 \mu \mathrm{m}$, in wastewater treatment plants is particularly challenging. This review aims to review the principle and application of different physical and chemical methods for the separation and removal of microplastic particles from aquatic environments, especially in water treatments process, with emphasis on some alternative and emerging separation methods. Advantages and disadvantages of conventional separation techniques such as clarification, sedimentation, floatation, activated sludge, sieving, filtration, and density separation are discussed. The advanced separation methods can be integrated with conventional techniques or utilize as a separate step for separating small microplastic particles. These advanced microplastic separation methods include membrane bioreactor, magnetic separation, micromachines, and degradation-based methods such as electrocatalysis, photocatalysis, biodegradation, and thermal degradation.
\end{abstract}

\section{Keywords}

microplastic separation, magnetic separation, membrane bioreactor, micromachines, wastewater treatment

\section{Introduction to microplastic occurrence and hazards} Plastic-based materials are widely used in today's life and cause a growing threat due to releasing various forms of plastic waste such as nano-, micro-, and macro-plastics are releasing into the environment [1]. During the last decade, microplastic particles (MPs) have entered directly into marine and freshwater environments, affecting habitats and animals negatively. Firstly, in the early 1970s, microplastics were reported in North America as spherules in plankton tows in coastal waters of New England [2]. Subsequently, microplastics are penetrating oceans and water bodies, including rivers and lakes progressively. Accordance to the National Oceanic and Atmospheric Administration (NOAA), microplastic particles are defined as plastic particles smaller than $5 \mathrm{~mm}$ in length. Microplastics can be categorized into two major classifications as primary and secondary microplastics, depending on their source [3]. Primary microplastics consist of industrial products such as cosmetics as well as different kinds of textiles [4-6]. Secondary microplastics form by the fragmenting larger plastic items, caused by weathering (e.g., ultraviolet light) and during consumption or fabrication [6-8]. Annually more than 348 million tons of plastic waste releases into aquatic environments. Fragmented polymeric particles less than $5 \mathrm{~mm}$ has potential toxic risks in the ecosystem and human health [9]. Fragmentation of polymeric waste decreases the size of plastic particles to micro- and nano-scale, which may be due to the effect of tides and waves [10].

Recent research revealed that more than 100 billion microplastics can be released by a single wastewater treatment plant (WWTP) yearly; hence WWTPs are substantial contributors to the issue of microplastic pollution of surface waters [11]. Additionally, microplastic particles in the effluent of the wastewater treatment plant penetrate the 
water bodies and pile up in the environment eventually, taking into account WWTPs may remove some of microplastics in light of used treatment units $[12,13]$.

Typically, microplastics refer to plastic particles with dimensions ranging from $100 \mathrm{~nm}$ to $5 \mathrm{~mm}$. This range includes sub-micron plastic particles $(100 \mathrm{~nm}-1 \mu \mathrm{m})$, small microplastics $(1-100 \mu \mathrm{m})$, and large microplastics $(100 \mu \mathrm{m}-5 \mathrm{~mm})$. Plastic particles smaller than $100 \mathrm{~nm}$ are classified as nanoplastics [14-17]. However, a threshold limit of $1000 \mathrm{~nm}$ is used in some studies related to environmental nanotechnology [17, 18]. As discussed in a comprehensive review by Yin et al. [19] on the toxicity of microplastics and nanoplastics, depending on the target organs, microplastics and nanoplastics show different toxicity. Microplastics with small sizes are more toxic than large ones because of the higher bioavailability and retention time in the body. Generally, nanoplastics with higher surface area seem to be more toxic than microplastics. Micro- and nano-plastic particles can accumulate in various tissues [20]. Depending on the organ type, the accumulation of plastic particles with nano- and micronsize are different [21]. Plastic particles with different components show different toxicity which arises from differences in their physicochemical properties [19].

The abundance of some polymer types as a percentage in wastewater treatment identified by Raman Spectrometer is shown in Fig. 1 [22]. Polyethylene and polystyrene as hydrophobic polymers with densities like water are some of the most abundant microplastics in drinking and freshwater systems [23, 24]. Microplastics are present in aquatic environments, sediments, and water treatment plant effluents [25].

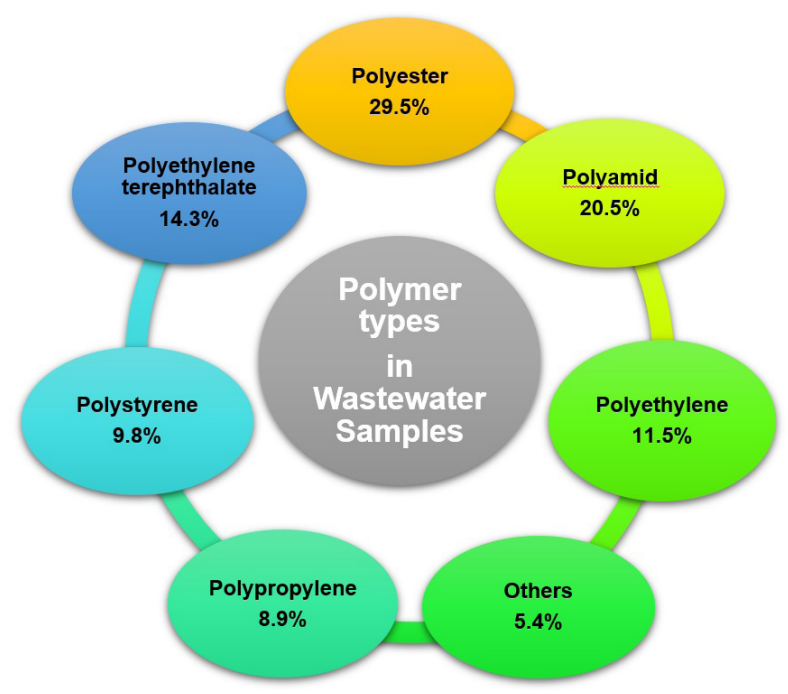

Fig. 1 Different types of polymers in wastewater samples detected by Raman Spectrometer [22].
Adsorption of hazardous substances such as metals or organic compounds on the surface of microplastic increases the chemical toxicity of hazardous. Long-term weathering of microplastics in aquatic systems provide sorption sites for metals or organic compounds $[9,26,27]$. Aquatic ecosystem is widely affected by plastic wastes as one of the most emerging contaminants with small size, low-density, and bioavailability to organisms. The hydrophobic nature and high surface area of microplastics facilitate the adsorption of organic pollutants and metals in aquatic systems [28]. Fossi et al. [29] studied the detection of microplastics as plastic debris on large filter feeders such as baleen whales and sharks. The results revealed that the concentration of Phthalate and organochlorines could be considered as a tracer for microplastic. Besseling et al. [30] reported microplastics of various types and sized in the baleen whale. FTIR analysis revealed the existence of various polymers such as polyethylene, polypropylene, polyvinylchloride, polyethylene terephthalate, and nylon of various shapes such as sheets and fragments with sizes larger than $1 \mathrm{~mm}$. Gonçalves et al. [31] assessed the ingestion and excretion of microplastics by exposing the Mediterranean mussel to polystyrene microplastics of 2 and $10 \mathrm{~mm} \mu \mathrm{m}$. The histopathological results revealed the potential ability of the Mediterranean mussel to digest and exert microplastics. Several studies are conducted to detect microplastic particles in food such as honey, sugar, beer, table salt, and drinking water [1]. Oral digestion of microplastics in food has topological harmful and small microplastic particles less than $1.5 \mu$ m may penetrate organs; therefore, it is essential to develop high precise methods for detecting small microplastic particles in food [32].

Additionally, microplastics due to their physicochemical properties can interact with metallic, inorganic, and organic matters and pollutants, and nutrients and create a suitable condition for microorganisms' attachment and colonization [33-35]. The attached microorganisms via their surrounded extracellular biopolymers or so-called biofilms have been studied extensively [36-39]. In addition to some effects of biofilm formation such as protecting the microplastics from abiotic and environmental stress and destruction, growth and enrichment of pathogenic bacteria and fungi and possible genetic materials' exchange between bacteria are the main concerns [40-44]. Microplastics can act as vectors for transferring the microorganisms and contaminating the environments [45, 46]. It is worth noting that many researches are focused on another aspect of the interaction between microplastics and microorganisms. Due to the potential of some bacteria 
and fungi in the enzymatic digestion of plastics, biological degradation of plastic materials attracts much attention in the last decades [47-50]. Since the focus of the review is microplastics' separation techniques, we refer the readers to good reviews published in recent years for more information on microplastics and microorganisms interactions [44, 51, 52].

This review provides a critical discussion on various techniques for microplastic particles separation from aquatic environments. In addition to the separation methods conventionally utilized in the wastewater treatment process, more recent advanced separation techniques such as membrane bioreactors, magnetic-based separation, micromachines, and degradation-based separation are presented and reviewed. The challenges and limitations of conventional techniques as well as the advantages of advanced techniques to separate small micron-size plastic particles from water have also been presented and discussed.

\section{Conventional methods of microplastic separation}

Studies related to the occurrence and removal of microplastics have attracted the attention of researchers, mainly about the removal of microplastics by applying different treatment techniques. The potential hazards of microplastics in our everyday life and the development of efficient methods for the characterization and quantification of polymeric particles of micron size in aquatic environments and sediments have been investigated in many researches [53].

Among various treatment methods in water treatment plants [54, 55], clarification, sedimentation, density separation, coagulation and, or flocculation, activated sludge, sieving and filtration are considered conventional treatment processes in water treatment plants, and several studies have been focused on the removal efficiency of these treatment process for microplastic separation [56]. The basis of various physical, chemical, and biological methods conventionally applied in water treatment plants has been reviewed by Tirkey and Upadhyay and Zhang et al. [57, 58].

The sedimentation process is limited for the separation of low-density particles. Unlike the cake filtration method, dept filtration is a suitable technique for microplastic separation from large volume and dilute aquatic samples. In contrast, dept filtration method suffers from a large pressure drop in this process [53].

A challenge encountered when trying to compare results from microplastic surveys is the lack of comparable protocols, for the identification of microplastic in the samples. In sampling protocols microplastics are usually, classify based on source, type, shape, color, and degradation stage. Identification is primarily made by visual identification, often with the aid of stereomicroscope. Researchers for sampling and analyzing plastics from natural particles use different protocols. There are some protocols for analysis of microplastic in aquatic samples based on visual analyzing and FTIR spectroscopy. The most common analysis methods are FTIR and Raman spectroscopies [59, 60].

Here we provide a brief explanation of the most common techniques utilized in water and wastewater treatment plants to remove small polymeric particles of micron size.

Primary clarification aims to provide solid settling before the biological treatment. Primary clarifiers are also supported by surface skimmers to skim floating solids off the surface before the secondary treatment. Michielssen et al. [61] observed that $84-88 \%$ of microparticles with sizes ranging from 100-1000 $\mu \mathrm{m}$, were eliminated through primary screening and primary clarification; Conley et al. [62] reported the loading of microplastics and their removal efficiency in three wastewater treatment plants with various treatment operations and service arrangements in USA for one year. The major wastewater treatment plant was using a primary clarification and demonstrated the highest microplastic removal efficiency of about $97.6 \%$ that clarifies the impact of primary clarifiers on microplastic removal performance. The size fractions included microplastic particles larger than $418 \mu \mathrm{m}$, between 178-418 $\mu \mathrm{m}$, and between 60-178 $\mu \mathrm{m}$ [62].

The sedimentation technique, which is based on gravitational settling, can remove suspended contaminants such as microplastic particles from aquatic systems. This method is used not only in primary treatment but also in secondary treatment. The removal efficiency of microplastics by sedimentation is affected by two crucial factors, including density and shape $[63,64]$. This process can be used before other treatment techniques [63, 64] with removal efficiencies of $57 \%-64 \%$ in wastewater of South Korea [65], which microbeads and fragments were reported as the major kinds of microplastics in all wastewater samples and $91.7 \%[66,67]$. The major drawback of the sedimentation technique is the essence of utilizing some other appropriate techniques in the following to complete removal.

Flotation is based on four steps. The steps include bubble generation in the wastewater, contact between the gas bubbles and suspended particles/oil droplets, attachment of the particle/oil droplets to the bubble surface, and finally rising the air-solid mixture for skimming off the floating materials [68]. There are several types of floatation, depending on 
the bubble generation method, such as dissolved air floatation (DAF), Induced air floatation (IAF), Froth floatation, electrolytic floatation, vacuum floatation [69]. Flotation is one of the most widely used methods for separating low-density plastic particles from soil or sediment in dense liquids [70]. Dissolved air floatation allows to remove of low-density particles and algae effectively; however, this method is expensive to operate and maintain compared with the sedimentation process [71]. Coppock et al. [15] proposed a portable density floatation to separate microplastics with particle sizes ranging from $100 \mu \mathrm{m}-10 \mathrm{~mm}$ from sediments with an average efficiency of $95.8 \%$.

Conventional activated sludge process (CASP) is a common wastewater treatment process, relying on biodegradation using activated sludge. Microplastic particles could attach to the suspended matter and separate in the subsequent settling step [67, 72]. Magni et al. [73] conducted a grid chamber and conventional activated sludge process at a municipal WWT system in Italy for microplastic separation with a $64 \%$ removal rate. In this study, the size classes included $1-5 \mathrm{~mm}, 0.5-1 \mathrm{~mm}, 0.1-0.5 \mathrm{~mm}$, and $0.01-0.1 \mathrm{~mm}$. The main drawbacks of CASP are producing an excessive sludge, extensive retention times, extensive sedimentation surface, and massive cost of energy and dumping. However, this process is flexible, appropriate for wide-scale treatments $[63,74-76]$. The retention time and nutrient extent in wastewater are considered as the most important affecting factors on the efficiency of the activated sludge method for microplastic removal [12, 77].

To investigate the impacts of microplastics as emerging pollutants, it is required to collect different types of microplastics from aquatic environments for identification through sampling and extraction techniques.

Filters with different pore structure, pore size, and materials are used for extracting the microplastics from aquatic samples. Metal-based filters such as stainless steel and polymer-based filters such as polycarbonate, nitrocellulose, and nylon are utilized for the separation of microplastics from retained particles [78, 79]. Some filter materials have curvy and deep pore structures such as stainless steel and nylon filters. Some others exhibited narrow and straight circular pores such as polycarbonate filters. The particles employed in the mesh filtration technique were in the range of 50-1000 $\mu \mathrm{m}$ [80]. After sampling, the retained microplastics on the filter are analyzed quantitatively and qualitatively. The analysis of the abundance and size distribution of retained microplastics are termed quantitative analysis. The qualitative analysis includes evaluating the color, shape, and composition of the retained microplastics [81]. In some studies, manta trawls and neuston nets are utilized as a sampling system from large volume aquatic environments such as oceans and water column [82]. It may be possible secondary contamination of water by filter fibers in filtration method. Therefore, it may be checked that the secondary contamination is reasonable in comparison with the removal of the primary microplastics.

The sieving method of water samples is also used to separate microplastics plentifully, resulting in sorting particles into different size ranges depending on the choice of sieve mesh size categories [83, 84]. The sieve physically traps the microplastic particles, enabling water to get lost from the sample [85]. Olivatto et al. [86] studied separate microplastics found in samples of the Guanabara Bay in Brazil via the sieving and manual sorting. Microplastic particles less than $5 \mathrm{~mm}$ were isolated in the laboratory by wet sieving using two meshes including $355 \mu \mathrm{m}$ in the bottom and $4.75 \mathrm{~mm}$ in the top. The most common sieving system for the separation of microplastics from water and sediment samples is multi-step sieving, which is using a series of sieves with different mesh size [87]. A cost-effective separation and quantifying method with less environmental footprint was presented by Gimiliani et al. [88] comprising sieving of 2.0,1.0, 0.5, and $0.25 \mathrm{~mm}$ mesh sizes, sediment collection, drying, and stereomicroscopic evaluation of the samples maintained on each sieve [88].

Density separation of microplastics is based on their different densities and is usually conducted by adding brine solutions to allow separating lower density particles from denser matrices after settlement [6, 15, 89, 90]. Konechnaya et al. [91] reported that $\mathrm{ZnCl}_{2}$-based density separation is an appropriate method for separating polymeric particles from a sandy sample for isolating the particles with sizes including 1-5 mm, 400-1000 $\mu \mathrm{m}, 200-400 \mu \mathrm{m}$, and 100-200 $\mu \mathrm{m}$. Applying a centrifugation step after density separation in saline solutions can enhance the plastic-sediment separation ability and improve the extraction capacity of microplastic fibers and granules from sediments [90, 92].

\section{Recent progress in conventional separation methods}

Removal of small microplastic particles less than $100 \mu \mathrm{m}$ is challenging since particles larger than $100 \mu \mathrm{m}$ can be sufficiently separated in today's water treatment plants [56, 93]. Wang et al. [56] studied the presence of various microplastics of $1-100 \mu \mathrm{m}$ in size such as polyethylene terephthalate, polyethylene, polypropylene, polyacrylamide with fiber, sphere, or fragment shapes in the 
effluent of different treatment processes of an advanced drinking water treatment plant (ADWTP) . Xia et al. [94] utilized the Fluorescence imaging method to evaluate the effect of tween 20 surfactants in ppm level on the coagulation of polystyrene microplastics of $1 \mu \mathrm{m}$. A flexible and hydrophilic layer formed on the microplastic particles by surfactant molecules hinders the deposition of bentonite. It inhibits agglomeration resulting in a decrement in the removal efficiency with increasing surfactant concentration, as shown in Fig. 2 [94]. In contrast, anionic surfactants such as sodium dodecyl sulfate will not hinder the coagulation of microplastic particles since negative charges induced by surfactant adsorption are neutralized in the presence of $\mathrm{Al}^{3+}$ ions resulting in the precipitation of microplastic particles. As shown in Fig. 2, the coagulation removal efficiency was not affected by increasing sodium dodecyl sulfate surfactant [94]. The coagulation integrated with sedimentation is an appropriate choice for contaminant removal [95]. Pivokonský et al. [96] reported microplastic removal of $88 \%$ using a multi-step process such as coagulation-flocculation with sedimentation. Coagulation-flocculation with sedimentation was quite effective for the elimination of microplastics, and additional MP removal was obtained by filtration and granular activated carbon processes. Ma et al. [97] examined microplastic removal in coagulation/sedimentation and ultrafiltration in controlled tests using Al- and Fe-based salts, observing a removal efficiency lower than $40 \%$.

Filtration system integrated with various separation techniques such as clarification, floatation, or reverse osmosis has been investigated in some studies [70, 98, 99].

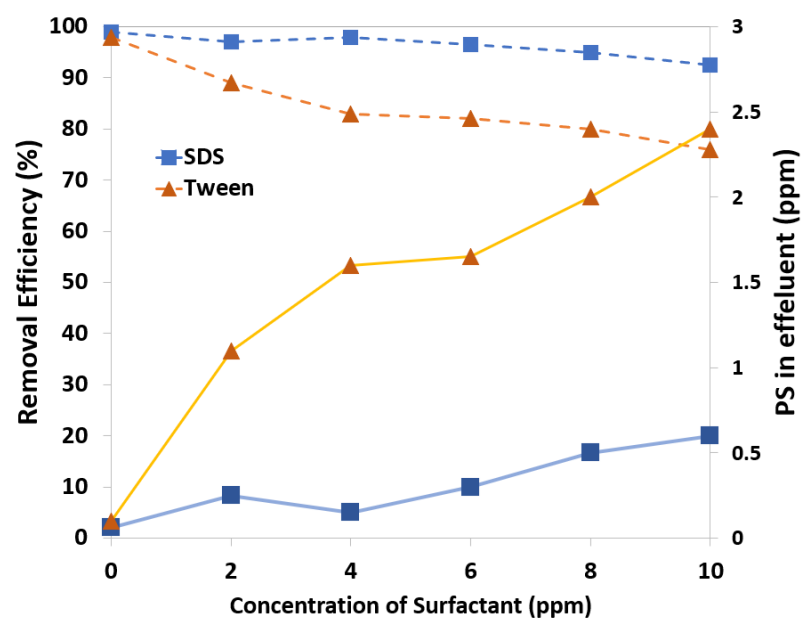

Fig. 2 The effect of surfactants on (left) the removal efficiency of polystyrene microplastics and (right) the residue concentration of microplastic particles in the effluent [94].
Kim and An [100] developed a vacuum-based method for separating microplastic LDPE films, for including two differently sized cylindrical sieves to accumulate film samples. Wang et al. [99] studied the occurrence of phthalate esters and microplastics at the effluent of four wastewater treatment plants, receiving water bodies in winter and spring. The main techniques were clarification, filtration, and reverse osmosis with removal rates of $42.7 \%-69.2 \%$, $25.3 \%-59.3 \%$, and $22.6 \%-51.0 \%$, respectively. The total removal rates of phthalate esters and microplastics in the four RWTPs were $47.7 \%-81.6 \%$ and $63.5 \%-95.4 \%$, respectively. The results revealed that the surrounding environment considerably affected the amount of phthalate esters and microplastics in surface waters.

Classification of microplastics before analysis seems to be required and useful since sedimentation velocity depends on particle density and size. Polymeric particles have various densities; some polymers are denser than water, and some others have densities close to or less than water. For small-size microplastics with a low sedimentation velocity of $1 \mathrm{~cm} / \mathrm{h}$, a filtration system should be designed based on the particle size rather than particle density [101]. Bannick et al. [101] developed a filtration system for analyzing microplastic samples in water using a thermal extraction-desorption gas chromatography-mass spectrometry (TED-GC-MS). The filtration system was validated for artificial water samples and was applied in the effluent of a WWTP in Berlin. Artificial water samples composed of spherical polyethylene and polystyrene particles with various sizes ranging from $22-150 \mu \mathrm{m}$ and $298 \mu \mathrm{m}$, respectively. The filtration system included several stainless-steel filters to classify microplastics into different size classes of 1000-500 $\mu \mathrm{m}, 500-100 \mu \mathrm{m}, 100-50 \mu \mathrm{m}$, and 50-10 $\mu \mathrm{m}$. The results revealed that the sampling and separation method depends on the size class of microplastic in water. This filtration method showed a recovery percent of 80-110, depending on the type and size of particles. For analyzing quantic samples using TED-GC-MS, the larger particles required a larger volume of water required to be sampled. For particles smaller than $50 \mu \mathrm{m}$, significantly smaller than $10 \mu \mathrm{m}$, it is required to apply pressure filtering due to the small effect of density in sedimentation of small polyethylene and polystyrene particles [101].

Anna Markiewicz et al. [102] assessed the performance of a pilot plant for the removal of non-particulate organic pollutants from urban runoff in Sweden. The separation system included a sand-column as pre-filter, which is in series with a granulated activated carbon, Sphagnum peat, or Pinus 
sylvestris bark column. All filters exhibited an effective removal of total suspended particles larger than $1.2 \mu \mathrm{m}$.

Automatic recognition of different microplastics, including polyethylene, polypropylene, and polystyrene with a size of $100 \mu \mathrm{m}$, is reported by Zhu et al. (2020) using a near-infrared hyperspectral imaging (HSI) technique. Gold-coated polycarbonate and glass microfiber filters showed a suitable performance for the identification of microplastics using the HSI technique [103].

\section{Advanced methods of microplastic separation}

Increasing demand for removing parts of microplastics that pass through conventional water and wastewater treatment plants is comprehensible. As reported in the literature [104-106], several advanced methods and technologies for removing micropollutants have been evaluated on a large scale in several countries such as Germany, Sweden, and Switzerland. Here we represent and discuss some of the advanced methods, including magnetic-based techniques such as magnetic seed filtration and magnetic micro-submarines [107], photocatalytic micro-motors [108], membrane bioreactors coupled with activated carbon filters, rapid sand filtration, or CAS [109] and degradation-based techniques such as electrocatalysis [110], photocatalysis [111, 112], biodegradation [113], and thermal degradation $[114,115]$.

\subsection{Membrane bioreactors}

Different technologies have been studied to remove microplastics from municipal and industrial wastewaters in real or pilot scales. Membrane bioreactor (MBR) is a established process for removing microplastics from wastewaters in real WWTPs or pilot scales [67, 98, 109]. The removal efficiency of the MBR process in several studies conducted in the Netherlands, China, the United States, the United Kingdom, and Finland are in the range of 64.4 to $99.9 \%$ [12, 13, 67, 109, 116, 117]. Membrane bioreactor is a growing technology in conventional water and wastewater treatment plants for replacing the conventional activated sludge technology in some countries such as Sweden. Membrane bioreactor is a combination of biological activated sludge process and membrane separation, which results in significant advantages over conventional activated sludge process for removing micropollutants in both municipal and industrial wastewater treatment plants [106]. Baresel et al. [106] evaluated a membrane bioreactor coupled with granulated active carbon-based biofilter for the removal of various kinds of micropollutants, including microplastics and organic compounds from real wastewater of Stockholm's main WWTP Henriksda with a hydraulic retention time of 10 hours. An ultrafiltration system was applied after the biological reactor. The effluent of the membrane bioreactor, with qualities of lower than $0.2 \mathrm{mg}$ $\mathrm{TP} / \mathrm{L}$ and $6 \mathrm{mg} \mathrm{TN} / \mathrm{L}$, was pumped to a granulated active carbon-based biofilter with a total area of $0.3 \mathrm{~m}^{2}$. A screening technique using a $20 \mu \mathrm{m}$ filters was applied to separate the microplastics from water samples. A stereo microscope with 50 times magnification was applied for counting and dividing microplastics into three groups of fragments, flakes, and fibers. Baresel et al. [106] found 100 percent removal efficiency for microplastics in the MBR effluent. Rapid sand filtration is a tertiary treatment in WWTPs, and its removal efficiency is compared with other technologies such as ozonation, membrane disc filter, and membrane bioreactor in some studies [65, 109]. Bayo et al. [109] found 14 polymer types in wastewater samples using membrane bioreactor and rapid sand filtration technologies and polyethylene, including low-density polyethylene (LDPE) and high-density polyethylene (HDPE) with $75.76 \%$, was the most common type in the samples. Different forms of microplastics including fibers, films, fragments, and beads with size ranging from $210 \mu \mathrm{m}$ to $6.3 \mathrm{~mm}$ were isolated in this study. About $58.90 \%$ of microplastics had sizes smaller than $1 \mathrm{~mm}$. Membrane bioreactor showed a removal percentage of about $79 \%$, which was more than that of rapid sand filtration, i.e., $75.5 \%$. Among various types of polymers, LDPE, nylon, and polyvinyl were remained in RSF effluent and melamine in MBR effluent [109].

\subsection{Magnetic based separation}

Microplastic recovery and extraction of small size lower than $150 \mu \mathrm{m}$ are challenging. Magnetic separation and extraction of microplastics such as polyethylene, polyethylene terephthalate, polystyrene, polyurethane, polyvinyl chloride, and polypropylene from various environmental matrices such as seawater, freshwater, and sediment can be considered as a post density separation step or a standalone process to produce a drinking water [107]. Magnetic seed filtration (MSF) technique includes two general steps: hetero-agglomeration of microplastic particles with magnetic nanoseeds, and separation of magnetized agglomerates using magnetic force [53, 107]. Compared with classic filtration methods, MSF has a lower pressure drop. There is no limit on the minimum size of microplastics for separation using the MSF method since the size dependency in this method can be tuned by varying the size and type of 
magnetic nanoparticles. Magnetic removal of organic dyes and heavy metals from wastewater using magnetic nanoparticles have been reported in the literature [118]. Moreover, the magnetic seed filtration technique showed promising results in large-scale water treatment. Hydrophobic and electrostatic interactions are introduced as main driving forces in the magnetic separation of microplastics from aquatic environments so far [53, 107]. Grbic et al. [107] developed a magnetic method based on using hydrophobic coated iron nanoparticle to recover microplastics even small-sized microparticles from seawater. This method was based on the magnetization of microplastic surfaces using hexadecyl trimethoxy silane functionalized-iron nanoparticles, microplastic with a higher surface to volume ratio, i.e., smaller microplastics, can be extracted more efficiently, see Fig. 3(A) [107]. The results revealed a separation recovery of $92 \%$ for microplastic particles smaller than $20 \mu \mathrm{m}$, including polyethylene and polystyrene beads, see Fig. 3(B), (C) [107]. Also, a recovery of 93\% obtained for microplastic particles larger than $1 \mathrm{~mm}$, including polyethylene, polyethylene terephthalate, polystyrene, polyurethane, polyvinyl chloride, and polypropylene. This method also applied for the separation of microplastics of $200 \mu \mathrm{m}$ to $1 \mathrm{~mm}$ from freshwater and sediments with recovery percent of $84 \%$ and $78 \%$, respectively.

\subsection{Micromachines}

One of the most promising technologies for environmental remediation and removal of contaminants such as oil, organic compounds, heavy metals, and microplastics from aquatic systems are self-propelled micro/nano-scale devices such as magnetic micro-submarines [119] and photocatalytic micro-motors [108]. Photocatalytic micromotors provide fascinating features, including an on/off switch, using water as green fuel and light as a renewable energy source [119]. Sun et al. [119] fabricated hollow
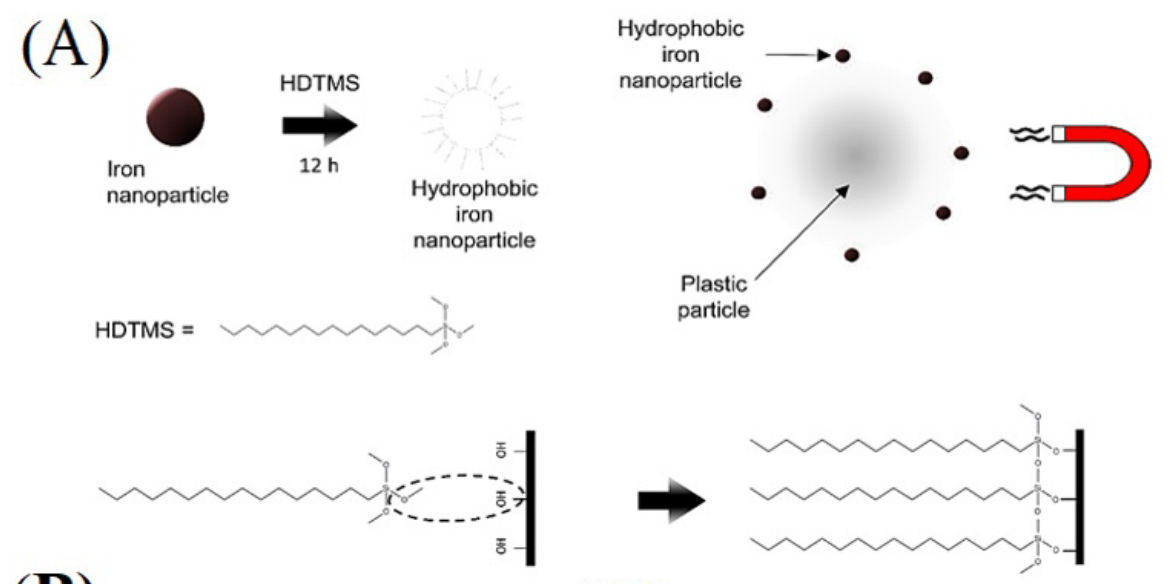

(B)

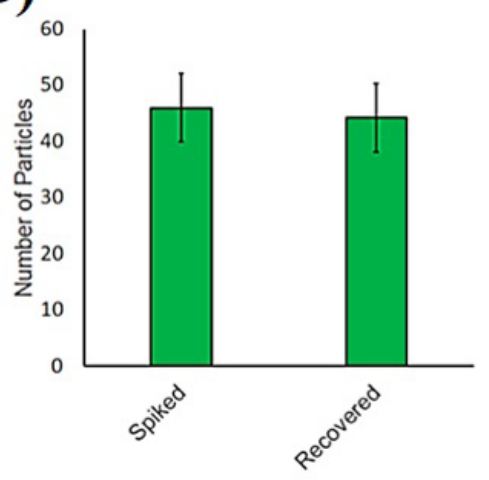

(C)

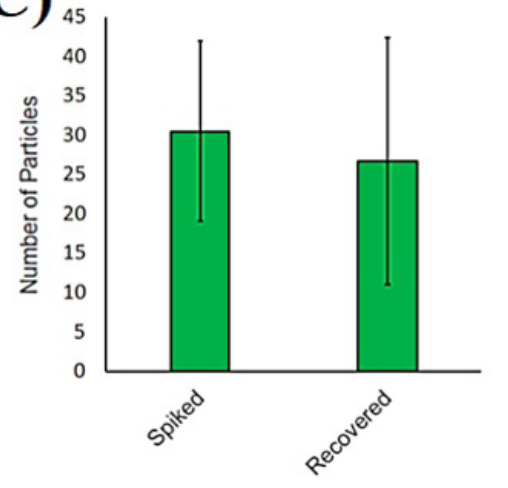

Fig. 3 (A) a schematic of synthesis procedure of hydrophobic iron nanoparticles using hexadecyltrimethoxysilane (HDTMS) functionalization and application for surface magnetization of microplastics for efficient extraction of small microplastic particles; (B) Number of small polyethylene spheres of less than $20 \mu \mathrm{m}$ in $1 \mu \mathrm{L}$ of spiked sample counting using microscope compared with magnetic extraction recovery; (C) Number of small polystyrene spheres of $15 \mu \mathrm{m}$ in $1 \mu \mathrm{L}$ of spiked sample counting using microscope compared with magnetic extraction recovery. Adapted with permission from [78]. Copyright (2019) American Chemical Society [107]. 
magnetic micro-submarines on a large-scale through sequential acidolysis and sputtering of natural sunflower pollen grains and applied for effective removal of oil and plastic particles from water. Hollow magnetic micro-submarines provided a recyclable, eco-friendly, and chemical-free method for microplastic removal through noncontact shoveling because of different fluid flow forces induced by the motion of micro-submarines in the aquatic environment. Wang et al. [108] developed photocatalytic micro-motors in the form of individual micro-motors and assembled a chain of catalytic particles based on $\mathrm{Au} @ \mathrm{Ni} @ \mathrm{TiO}_{2}$ structures. The results proved the ability of light-driven micro-motors for catalytic elimination of microplastics from aquatic samples.

\subsection{Degradation based separation}

Efficient degradation of microplastics into small and valuable substances, known as chemical recovery methods, is one of the promising and under-developing approaches to decrease the serious environmental severe of realizing fine polymeric particles such as polyvinyl chloride in aquatic systems. The produced substances can be reused as fuel or chemical feedstock. Chlorine residue in oil products obtained from polyvinyl chloride waste limits the application of chemical recovery methods. Simultaneous dichlorination and degradation of the polymeric chain are required to develop a sustainable and rapid process for polyvinyl chloride waste chemical recovery [110]. Kang et al. [120] synthesized magnetic spring-like carbon nanotubes (Mn@NCNT) and evaluated polyethylene-based microplastics degradation performance of robust hybrid carbon based-catalysts via oxidation and hydrothermal hydrolysis with 50\% removal efficiency. Toxicity analysis proved a green strategy since all organic intermediates were eco-friendly to the aquatic organisms. Highly stable catalytic performance of Mn@NCNT hybrid catalyst was attributed to the synergetic effects of robust structure, $\mathrm{Mn}$ encapsulation, and nitrogen doping, which reduce required activation energy. Miao et al. [110] applied a heterogeneous electro-Fenton like approach for degradation of polyvinyl chloride (PVC) in water using $\mathrm{TiO}_{2} /$ graphite cathode through simultaneous reductive dechlorination and radical oxidation of PVC with $56 \mathrm{wt} \%$ removal and dechlorination efficiency of $75 \%$ at $-0.7 \mathrm{~V}, 100{ }^{\circ} \mathrm{C}$ for $6 \mathrm{~h}$. During the electrocatalytic process, polyvinyl chloride microplastics obtained electrons from the cathode which resulted in the removal of chlorine followed by oxidation of polymeric chain and production of organic intermediates such as carbocyclic acids, alcohols, and esters, which finally converted to $\mathrm{CO}_{2}$ and $\mathrm{H}_{2} \mathrm{O}$ [110]. Ariza-Tarazona et al. [121] studied the visible light catalytic degradation of HDPE microplastics from water using protein-derived $\mathrm{C}, \mathrm{N}-\mathrm{TiO}_{2}$ semiconductor catalyst. The best degradation performance was obtained at a low temperature of $0^{\circ} \mathrm{C}$ and a low $\mathrm{pH}$ value of 3 due to the combined effect of $\mathrm{pH}$ and temperature on releasing more $\mathrm{H}^{+}$ions to the aquatic system and polymer fragmentation. Nabi et al. [122] studied the photocatalytic degradation of polystyrene microspheres and polyethylene microplastic particles using $\mathrm{TiO}_{2}$ nanoparticle films as a green and cost-effective removal method. Over $12 \mathrm{~h}$ illumination of UV light, over $98 \%$ degradation of $400 \mathrm{~nm}$ polystyrene microspheres was achieved, while faster photocatalytic degradation of polyethylene microplastic was reported over $36 \mathrm{~h}$ of UV illumination.

A large portion of released microplastics to aquatic systems are related to textile microfibers such as polyethylene terephthalate, and cellulose-based fibers entered to wastewater system from the effluent of cloths laundering [25]. The pure carbon structure of some extensively useful polymers, including polypropylene, polyethylene, and polyethylene terephthalate, restrict biodegradation using conventional techniques [123]. Compared with photocatalysis [111], electrocatalysis [110], and thermal degradation [114] methods, biodegradation of microplastics has particular strengths such as low operational cost, no need of chemicals, and being applicable for various polymeric particles [48, 124]. Periphytic biofilm was used by Shabbir et al. [48] for biodegradation of different microplastics, including polypropylene, polyethylene, and polyethylene terephthalate in the presence of glucose as an additional carbon source. The results revealed a weight loss ranging from $5.95-14.02 \%$ for PP, from 13.24 to $19.72 \%$ for PE and from $13.24-19.72 \%$ for PET biodegradation after 60 days. $\mathrm{Li}$ et al. [125] investigated the effect of prothioconazole as a broad-spectrum fungicide on the degradation of polyethylene and polybutyleneadipote-co-terphthalate (PBAT) microplastics. Biodegradable PBAT microplastics were degraded faster than polyethylene. Degradation of Polyglycerol maleate microbeads of $30 \mu \mathrm{m}$ as a biodegradable microplastic was evaluated by Hsieh et al. [126] in different aquatic systems such as buffer solution, enzyme solution, deionized water, and seawater. Complete decomposition of microplastics was observed in alkaline solution for $45 \mathrm{~min}$, attributed to surface erosion mechanism. Biodegradation of LDPE using Pseudomonas aeruginosa 
ISJ14 via biofilm formation on the polymer surface by microorganisms was proved by Gupta and Devi [127].

\section{Conclusion}

The occurrence and impacts of plastic particles in water bodies progressively spread worldwide. As reported in the literature, million tons of plastic particles of micron- and nano-size are released into the aquatic environment annually. Studies on microplastic hazards and separation have been growing over the past decade. Many methods have been developed and evaluated on account of the current studies on microplastic particles, which will facilitate to fill the research gap in the future.

Some advanced separation techniques capable of removing small microplastic particles include membrane bioreactors, magnetic-based recoveries, electrocatalytic degradation, photocatalytic degradation, biological degradation, and thermal degradation techniques. Some studies reported almost the same separation efficiency using membrane bioreactor and rapid sand filtration compared with the conventional methods such as activated sludge and removing fiber-like microplastics seems to be challenging by these advanced methods. Magnetic-based adsorbents are introduced as a novel recyclable approach with high adsorption efficiency for microplastic separation with economic feasibility. In some studies, magnetic separation is introduced as an efficient and fast extraction method for clean samples, and it is recommended to utilize as a post-density or post-digestion step in water treatment plants. Applying a continuous collecting system such as rotary magnetic drums in magnetic separation is recommended as well. Recyclable and reusable microsubmarines are developed as a new and environmentally adaptive approach for removing microplastic particles with no need to adding other chemicals. Regarding UV-, or visible light photocatalytic degradation of microplastic particles using carbon nitrides, functionalized $\mathrm{ZnO}$, and $\mathrm{TiO}_{2}$, there is a gap in evaluating the operating parameters such as $\mathrm{pH}$ and temperature. It is also required more investigations to

\section{References}

[1] Ossmann, B. E., Sarau, G., Schmitt, S. W., Holtmannspötter, H., Christiansen, S. H., Dicke, W. "Development of an optimal filter substrate for the identification of small microplastic particles in food by micro-Raman spectroscopy", Analytical and Bioanalytical Chemistry, 409(16), pp. 4099-4109, 2017. https://doi.org/10.1007/s00216-017-0358-y

[2] Carpenter, E.J., Anderson, S. J., Harvey, G. R., Miklas, H. P., Peck, B. B. "Polystyrene Spherules in Coastal Waters", Science, 178(4062), pp. 749-750, 1972. https://doi.org/10.1126/science.178.4062.749 develop a new photocatalyst for complete degradation of microplastics in water. Fragmentation of microplastic particles through the photocatalytic process facilitates degradation through increasing the surface area and interaction between plastic particles and photocatalyst.

There are two general approaches to developing new separation methods in the literature. The first approach is sampling and identifying microplastics in water samples of freshwater bodies or the effluent of WWTPs based on sieving, filtration, and density separation methods. The other approach is removing microplastic particles of various types and sizes using conventional wastewater treatment processes or using integrating new techniques with conventional treatments.

\section{Future remarks}

There are few reports on the mathematical analysis and modeling of conventional and advanced separation techniques in wastewater treatment to have an effective plant operation. For a more accurate understanding of the environmental consequences of microplastic particles, future investigations should concentrate on the development of new modeling techniques to evaluate the transport route of microplastic particles in the soil, sediments, and water. It is also required to evaluate the impact of organism adsorption on the surface properties of microplastics and their fragmentation.

Despite conducting many attempts to develop approaches for separating and identifying microplastic particles, establishing practical and reliable standard protocols for quantifying microplastic particles with different shapes, sizes, and densities in water bodied and wastewater treatment plants is essential. It is demanding to standardize sieving, chemical digestion, density separation, and visual separation methods in the wastewater treatment plants. In conclusion, an appropriate remedy can be the identification and removal of microplastic resources and penetration routes to monitor inventories of materials or employ novel devices and methods.

[3] Arthur, C., Baker, J., Bamford, H. "Proceedings of the International Research Workshop on the Occurrence, Effects, and Fate of Microplastic Marine Debris", [pdf] National Oceanic and Atmospheric Administration, Silver Spring, MD, USA 2009. Available at: https://marinedebris.noaa.gov/file/2192/download?token=5dvqb-YY [Accessed: 09 September 2008] 
[4] Browne, M. A., Crump, P., Niven, S. J., Teuten, E., Tonkin, A., Galloway, T., Thompson, R. "Accumulation of Microplastic on Shorelines Woldwide: Sources and Sinks", Environmental Science \& Technology, 45(21), pp. 9175-9179, 2011.

https://doi.org/10.1021/es201811s

[5] Cooper, D. A., Corcoran, P. L. "Effects of mechanical and chemical processes on the degradation of plastic beach debris on the island of Kauai, Hawaii", Marine Pollution Bulletin, 60(5), pp. 650-654, 2010.

https://doi.org/10.1016/j.marpolbul.2009.12.026

[6] Thompson, R. C., Olsen, Y., Mitchell, R. P., Davis, A., Rowland, S. J., John, A. W. G., McGonigle, D., Russell, A. E. "Lost at Sea: Where Is All the Plastic?", Science, 304(5672), p. 838, 2004

https://doi.org/10.1126/science.1094559

[7] Anderson, S. C., Cooper, A. B., Jensen, O. P., Minto, C., Thorson, J. T., Walsh, J. C.,..., Selig, E. R. "Improving estimates of population status and trend with superensemble models", Fish and Fisheries, 18(4), pp. 732-741, 2017.

https://oi.org/10.1111/faf.12200

[8] Ballent, A., Corcoran, P. L., Madden, O., Helm, P. A., Longstaffe, F. J. "Sources and sinks of microplastics in Canadian Lake Ontario nearshore, tributary and beach sediments", Marine Pollution Bulletin, 110(1), pp. 383-395, 2016.

https://doi.org/10.1016/j.marpolbul.2016.06.037

[9] Ye, S., Cheng, M., Zeng, G., Tan, X., Wu, H., Liang, J., .., Zhang, Y. "Insights into catalytic removal and separation of attached metals from natural-aged microplastics by magnetic biochar activating oxidation process", Water Research, 179, Article number: 115876, 2020.

https://doi.org/10.1016/j.watres.2020.115876

[10] Wang, F., Wang, B., Qu, H., Zhao, W., Duan, L., Zhang, Y., Zhou, Y., $\mathrm{Yu}, \mathrm{G}$. "The influence of nanoplastics on the toxic effects, bioaccumulation, biodegradation and enantioselectivity of ibuprofen in freshwater algae Chlorella pyrenoidosa", Environmental Pollution, 263(B), Article number: 114593, 2020.

https://doi.org/10.1016/j.envpol.2020.114593

[11] Freeman, S., Booth, A. M., Sabbah, I., Tiller, R., Dierking, J., Klun, K., ..., Angel, D. L. "Between source and sea: The role of wastewater treatment in reducing marine microplastics", Journal of Environmental Management, 266, Article number: 110642, 2020. https://doi.org/10.1016/j.jenvman.2020.110642

[12] Carr, S. A., Liu, J., Tesoro, A. G. "Transport and fate of microplastic particles in wastewater treatment plants", Water Research, 91, pp. 174-182, 2016

https://doi.org/10.1016/j.watres.2016.01.002

[13] Murphy, F., Ewins, C., Carbonnier, F., Quinn, B. "Wastewater Treatment Works (WwTW) as a Source of Microplastics in the Aquatic Environment", Environmental Science \& Technology, 50(11), pp. 5800-5808, 2016.

https://doi.org/10.1021/acs.est.5b05416

[14] Schymanski, D., Oßmann, B. E., Benismail, N., Boukerma, K., Dallmann, G., von der Esch, E., ..., Ivleva, N. P. "Analysis of microplastics in drinking water and other clean water samples with micro-Raman and micro-infrared spectroscopy: minimum requirements and best practice guidelines", Analytical and Bioanalytical Chemistry, 413(24), pp. 5969-5994, 2021. https://doi.org/10.1007/s00216-021-03498-y
[15] Coppock, R. L., Cole, M., Lindeque, P. K., Queirós, A. M., Galloway, T. S. "A small-scale, portable method for extracting microplastics from marine sediments", Environmental Pollution, 230, pp. 829-837, 2017. https://doi.org/10.1016/j.envpol.2017.07.017

[16] Koelmans, A. A., Besseling, E., Shim, W. J. "Nanoplastics in the Aquatic Environment. Critical Review", In: Bergmann, M., Gutow, L., Klages, M. (eds.) Marine Anthropogenic Litter, Springer International Publishing, Cham, Switzerland, 2015, pp. 325-340. https://doi.org/10.1007/978-3-319-16510-3_12

[17] Nguyen, B., Claveau-Mallet, D., Hernandez, L. M., Xu, E. G., Farner, J. M., Tufenkji, N. "Separation and Analysis of Microplastics and Nanoplastics in Complex Environmental Samples", Accounts of Chemical Research, 52(4), pp. 858-866, 2019. https://doi.org/10.1021/acs.accounts.8b00602

[18] Murray, A., Örmeci, B. "Removal Effectiveness of Nanoplastics $(<400 \mathrm{~nm})$ with Separation Processes Used for Water and Wastewater Treatment", Water, 12(3), Article number: 635, 2020. https://doi.org/10.3390/w12030635

[19] Yin, K., Wang, Y., Zhao, H., Wang, D., Guo, M., Mu, M., ..., Xing, M. "A comparative review of microplastics and nanoplastics: Toxicity hazards on digestive, reproductive and nervous system", Science of The Total Environment, 774, Article number: 145758, 2021.

https://doi.org/10.1016/j.scitotenv.2021.145758

[20] Zitouni, N., Bousserrhine, N., Missawi, O., Boughattas, I., Chèvre, N., Santos, R., ..., Banni, M. "Uptake, tissue distribution and toxicological effects of environmental microplastics in early juvenile fish Dicentrarchus labrax", Journal of Hazardous Materials, 403, Article number: 124055, 2021. https://doi.org/10.1016/j.jhazmat.2020.124055

[21] Qiang, L., Cheng, J. "Exposure to polystyrene microplastics impairs gonads of zebrafish (Danio rerio)", Chemosphere, 263, Article number: 128161,2021 https://doi.org/10.1016/j.chemosphere.2020.128161

[22] Jiang, J., Wang, X., Ren, H., Cao, G., Xie, G., Xing, D., Liu, B. "Investigation and fate of microplastics in wastewater and sludge filter cake from a wastewater treatment plant in China", Science of The Total Environment, 746, Article number: 141378, 2020. https://doi.org/10.1016/j.scitotenv.2020.141378

[23] Koelmans, A. A., Mohamed Nor, N. H., Hermsen, E., Kooi, M., Mintenig, S. M., De France, J. "Microplastics in freshwaters and drinking water: Critical review and assessment of data quality", Water Research, 155, pp. 410-422, 2019. https://doi.org/10.1016/j.watres.2019.02.054

[24] Zhang, Y., Diehl, A., Lewandowski, A., Gopalakrishnan, K., Baker, T. "Removal efficiency of micro- and nanoplastics $(180 \mathrm{~nm}-125 \mu \mathrm{m})$ during drinking water treatment", Science of The Total Environment, 720, Article number: 137383, 2020. https://doi.org/10.1016/j.scitotenv.2020.137383

[25] Zambrano, M. C., Pawlak, J. J., Daystar, J., Ankeny, M., Goller, C. C., Venditti, R. A. "Aerobic biodegradation in freshwater and marine environments of textile microfibers generated in clothes laundering: Effects of cellulose and polyester-based microfibers on the microbiome", Marine Pollution Bulletin, 151, Article number: 110826,2020 https://doi.org/10.1016/j.marpolbul.2019.110826 
[26] Hodson, M. E., Duffus-Hodson, C. A., Clark, A., PrendergastMiller, M. T., Thorpe, K. L. "Plastic Bag Derived-Microplastics as a Vector for Metal Exposure in Terrestrial Invertebrates", Environmental Science \& Technology, 51(8), pp. 4714-4721, 2017. https://doi.org/10.1021/acs.est.7b00635

[27] Carbery, M., O'Connor, W., Palanisami, T. "Trophic transfer of microplastics and mixed contaminants in the marine food web and implications for human health", Environment International, 115, pp. 400-409, 2018.

https://doi.org/10.1016/j.envint.2018.03.007

[28] Sathish, N., Jeyasanta, K. I., Patterson, J. "Abundance, characteristics and surface degradation features of microplastics in beach sediments of five coastal areas in Tamil Nadu, India", Marine Pollution Bulletin, 142, pp. 112-118, 2019.

https://doi.org/10.1016/j.marpolbul.2019.03.037

[29] Fossi, M. C., Coppola, D., Baini, M., Giannetti, M., Guerranti, C., Marsili, L., ..., Clò, S. "Large filter feeding marine organisms as indicators of microplastic in the pelagic environment: The case studies of the Mediterranean basking shark (Cetorhinus maximus) and fin whale (Balaenoptera physalus)", Marine Environmental Research, 100, pp. 17-24, 2014.

https://doi.org/10.1016/j.marenvres.2014.02.002

[30] Besseling, E., Foekema, E. M., Van Franeker, J. A., Leopold, M. F., Kühn, S., Bravo Rebolledo, E. L., ..., Koelmans, A. A. "Microplastic in a macro filter feeder: Humpback whale Megaptera novaeangliae", Marine Pollution Bullettin, 95(1), pp. 248-252, 2015. https://doi.org/10.1016/j.marpolbul.2015.04.007

[31] Gonçalves, C., Martins, M., Sobral, P., Costa, P. M., Costa, M. H. "An assessment of the ability to ingest and excrete microplastics by filter-feeders: A case study with the Mediterranean mussel", Environmental Pollution, 245, pp. 600-606, 2019. https://doi.org/10.1016/j.envpol.2018.11.038

[32] EFSA Panel on Contaminants in the Food Chain (CONTAM) "Presence of microplastics and nanoplastics in food, with particular focus on seafood", EFSA Journal, 14(6), Article number: e04501, 2016. https://doi.org/10.2903/j.efsa.2016.4501

[33] Richard, H., Carpenter, E. J., Komada, T., Palmer, P. T., Rochman, C. M. "Biofilm facilitates metal accumulation onto microplastics in estuarine waters", Science of The Total Environment, 683, pp. 600-608, 2019. https://doi.org/10.1016/j.scitotenv.2019.04.331

[34] Rosato, A., Barone, M., Negroni, A., Brigidi, P., Fava, F., Xu, P., Candela, M., Zanaroli, G. "Microbial colonization of different microplastic types and biotransformation of sorbed PCBs by a marine anaerobic bacterial community", Science of The Total Environment, 705, Article number: 135790, 2020. https://doi.org/10.1016/j.scitotenv.2019.135790

[35] Saygin, H., Baysal, A. "Biofilm Formation of Clinically Important Bacteria on Bio-Based and Conventional Micro/SubmicronSized Plastics", Bulletin of Environmental Contamination and Toxicology, 105(1), pp. 18-25, 2020. https://doi.org/10.1007/s00128-020-02876-z
[36] Yang, Y. Liu, W., Zhang, Z., Grossart, H.-P., Gadd, G. M. "Microplastics provide new microbial niches in aquatic environments", Applied Microbiology and Biotechnology, 104(15), pp. 6501-6511, 2020. https://doi.org/10.1007/s00253-020-10704-x

[37] Tribedi, P., Sil, A. K. "Low-density polyethylene degradation by Pseudomonas sp. $\mathrm{AKS}_{2}$ biofilm", Environmental Science and Pollution Research, 20(6), pp. 4146-4153, 2013. https://doi.org/10.1007/s11356-012-1378-y

[38] Schlundt, C., Mark Welch, J. L., Knochel, A. M., Zettler, E. R., Amaral-Zettler, L. A. "Spatial structure in the "Plastisphere": Molecular resources for imaging microscopic communities on plastic marine debris", Molecular Ecology Resources, 20(3), pp. 620-634, 2020. https://doi.org/10.1111/1755-0998.13119

[39] Zettler, E. R., Mincer, T. J., Amaral-Zettler, L. A. "Life in the 'Plastisphere': Microbial Communities on Plastic Marine Debris", Environmental Science \& Technology, 47(13), pp. 7137-7146, 2013. https://doi.org/10.1021/es401288x

[40] Wu, X., Pan, J., Li, M., Li, Y., Bartlam, M., Wang, Y. "Selective enrichment of bacterial pathogens by microplastic biofilm", Water Research, 165, Article number: 114979, 2019. https://doi.org/10.1016/j.watres.2019.114979

[41] Tu, C., Chen, T., Zhou, Q., Liu, Y., Wei, J., Waniek, J. J., Luo, Y. "Biofilm formation and its influences on the properties of microplastics as affected by exposure time and depth in the seawater", Science of The Total Environment, 734, Article number: 139237, 2020.

https://doi.org/10.1016/j.scitotenv.2020.139237

[42] Eckert, E. M., Di Cesare, A., Kettner, M. T., Arias-Andres, M., Fontaneto, D., Grossart, H. P., Corno, G. "Microplastics increase impact of treated wastewater on freshwater microbial community", Environmental Pollution, 234, pp. 495-502, 2018. https://doi.org/10.1016/j.envpol.2017.11.070

[43] Arias-Andres, M., Klümper, U., Rojas-Jimenez, K., Grossart, H. P. "Microplastic pollution increases gene exchange in aquatic ecosystems", Environmental Pollution, 237, pp. 253-261, 2018. https://doi.org/10.1016/j.envpol.2018.02.058

[44] Lear, G., Kingsbury, J. M., Franchini, S., Gambarini, V., Maday, S. D. M., Wallbank, J. A., Weaver, L., Pantos, O. "Plastics and the microbiome: impacts and solutions", Environmental Microbiome, 16(1), Article number: 2, 2021. https://doi.org/10.1186/s40793-020-00371-w

[45] Kirstein, I. V., Kirmizi, S., Wichels, A., Garin-Fernandez, A., Erler, R., Löder, M., Gerdts, G. "Dangerous hitchhikers? Evidence for potentially pathogenic Vibrio spp. on microplastic particles", Marine Environmental Research, 120, pp. 1-8, 2016. https://doi.org/10.1016/j.marenvres.2016.07.004

[46] Song, J., Jongmans-Hochschulz, E., Mauder, N., Imirzalioglu, C., Wichels, A., Gerdts, G. "The Travelling Particles: Investigating microplastics as possible transport vectors for multidrug resistant E. coli in the Weser estuary (Germany)", Science of The Total Environment, 720, Article number: 137603, 2020. https://doi.org/10.1016/j.scitotenv.2020.137603 
[47] Syranidou, E., Karkanorachaki, K., Amorotti, F., Repouskou, E., Kroll, K., Kolvenbach, B., ..., Kalogerakis, N. "Development of tailored indigenous marine consortia for the degradation of naturally weathered polyethylene films", PLOS One, 12(8), Article number: e0183984, 2017.

https://doi.org/10.1371/journal.pone.0183984

[48] Shabbir, S., Faheem, M., Ali, N., Kerr, P. G., Wang, L. F., Kuppusamy, S., Li, Y. "Periphytic biofilm: An innovative approach for biodegradation of microplastics", Science of The Total Environment, 717, Article number: 137064, 2020.

https://doi.org/10.1016/j.scitotenv.2020.137064

[49] Devi, R. S., Kannan, V. R., Nivas, D., Kannan, K., Chandru, S., Antony, A. R. "Biodegradation of HDPE by Aspergillus spp. from marine ecosystem of Gulf of Mannar, India", Marine Pollution Bulletin, 96(1-2), pp. 32-40, 2015.

https://doi.org/10.1016/j.marpolbul.2015.05.050

[50] Morohoshi, T., Ogata, K., Okura, T., Sato, S. "Molecular Characterization of the Bacterial Community in Biofilms for Degradation of Poly(3-Hydroxybutyrate-co-3-Hydroxyhexanoate) Films in Seawater", Microbes and Environments, 33(1), pp. 19-25, 2018.

https://doi.org/10.1264/jsme2.ME17052

[51] Jacquin, J., Cheng, J., Odobel, C., Pandin, C., Conan, P., PujoPay, M., ..., Ghiglione, J. F. "Microbial Ecotoxicology of Marine Plastic Debris: A Review on Colonization and Biodegradation by the "Plastisphere"", Frontiers in Microbiology, 10, pp. 1-16, 2019. https://doi.org/10.3389/fmicb.2019.00865

[52] Yuan, J., Ma, J., Sun, Y., Zhou, T., Zhao, Y., Yu, F. "Microbial degradation and other environmental aspects of microplastics/ plastics", Science of The Total Environment, 715, Article number: 136968, 2020.

https://doi.org/10.1016/j.scitotenv.2020.136968

[53] Rhein, F., Scholl, F., Nirschl, H. "Magnetic seeded filtration for the separation of fine polymer particles from dilute suspensions: Microplastics", Chemical Engineering Science, 207, pp. 1278-1287, 2019.

https://doi.org/10.1016/j.ces.2019.07.052

[54] Şimşek, B., Sevgili, İnci, Ceran, Özge B., Korucu, H., Şara, O. N. "Nanomaterials Based Drinking Water Purification: Comparative Study with a Conventional Water Purification Process", Periodica Polytechnica Chemical Engineering, 63(1), pp. 96-112, 2019. https://doi.org/10.3311/PPch.12458

[55] Bakos, V., Szombathy, P., Simon, J., Jobbágy, A. "Implementing Cost-effective Co-treatment of Domestic and Food-industrial Wastewater by Novel Methods for Estimating Industrial Load", Periodica Polytechnica Chemical Engineering, 64(4), pp. 505-513, 2020.

https://doi.org/10.3311/PPch.15306

[56] Wang, Z., Lin, T., Chen, W. "Occurrence and removal of microplastics in an advanced drinking water treatment plant (ADWTP)", Science of The Total Environment, 700, Article number: 134520, 2020.

https://doi.org/10.1016/j.scitotenv.2019.134520

[57] Tirkey, A., Upadhyay, L. S. B. "Microplastics: An overview on separation, identification and characterization of microplastics", Marine Pollution Bulletin, 170, Article number: 112604, 2021.

https://doi.org/10.1016/j.marpolbul.2021.112604
[58] Zhang, Y., Jiang, H., Bian, K., Wang, H., Wang, C. "A critical review of control and removal strategies for microplastics from aquatic environments", Journal of Environmental Chemical Engineering, 9(4), Article number: 1054603, 2021.

https://doi.org/10.1016/j.jece.2021.105463

[59] Karlsson, T. M., Kärrman, A., Rotander, A., Hassellöv, M. "Comparison between manta trawl and in situ pump filtration methods, and guidance for visual identification of microplastics in surface waters", Environmental Science and Pollution Research, 27(5), pp. 5559-5571, 2020. https://doi.org/10.1007/s11356-019-07274-5

[60] Renner, G., Schmidt, T. C., Schram, J. "Analytical methodologies for monitoring micro(nano)plastics: Which are fit for purpose?", Current Opinion in Environmental Science \& Health, 1, pp. 55-61, 2018.

https://doi.org/10.1016/j.coesh.2017.11.001

[61] Michielssen, M. R., Michielssen, E. R., Ni, J., Duhaime, M. B. "Fate of microplastics and other small anthropogenic litter (SAL) in wastewater treatment plants depends on unit processes employed", Environmental Science: Water Research \& Technology, 2(6), pp. 1064-1073, 2016. https://oi.org/10.1039/C6EW00207B

[62] Conley, K., Clum, A., Deepe, J., Lane, H., Beckingham, B. "Wastewater treatment plants as a source of microplastics to an urban estuary: Removal efficiencies and loading per capita over one year", Water Research X, 3, Article number: 100030, 2019. https://doi.org/10.1016/j.wroa.2019.100030

[63] Bui, X. T., Vo, T. D. H., Nguyen, P. T., Nguyen, V. T., Dao, T. S., Nguyen, P. D. "Microplastics pollution in wastewater: Characteristics, occurrence and removal technologies", Environmental Technology \& Innovation, 19, Article number: 101013, 2020. https://doi.org/10.1016/j.eti.2020.101013

[64] Ngo, P. L., Pramanik, B. K., Shah, K., Roychand, R. "Pathway, classification and removal efficiency of microplastics in wastewater treatment plants", Environmental Pollution, 255(2), Article number: 113326,2019

https://doi.org/10.1016/j.envpol.2019.113326

[65] Hidayaturrahman, H., Lee, T. G. "A study on characteristics of microplastic in wastewater of South Korea: Identification, quantification, and fate of microplastics during treatment process", Marine Pollution Bulletin, 146, pp. 696-702, 2019. https://doi.org/10.1016/j.marpolbul.2019.06.071

[66] Gies, E. A., LeNoble, J. L., Noël, M., Etemadifar, A., Bishay, F., Hall, E. R., Ross, P. S. "Retention of microplastics in a major secondary wastewater treatment plant in Vancouver, Canada", Marine Pollution Bulletin, 133, pp. 553-561, 2018. https://doi.org/10.1016/j.marpolbul.2018.06.006

[67] Lares, M., Ncibi, M. C., Sillanpää, M., Sillanpää, M. "Occurrence, identification and removal of microplastic particles and fibers in conventional activated sludge process and advanced MBR technology", Water Research, 133, pp. 236-246, 2018. https://doi.org/10.1016/j.watres.2018.01.049 
[68] Shammas, N. K., Bennett, G. F. "Principles of Air Flotation Technology", In: Wang, L. K., Shammas, N. K., Selke, W. A., Aulenbach, D. B. (eds.) Flotation Technology, Handbook of Enviromental Engineering, Humana Press, Totowa, NJ, USA, 2010, pp. 1-47.

https://doi.org/10.1007/978-1-60327-133-2_1

[69] Wang, L. K., Shammas, N. K., Selke, A. W., Aulenbach, D. B. "Flotation Technology,Handbook Of Environmental Engineering", Humana Press, Totowa, NJ, USA, 2010.

[70] Han, X., Lu, X., Vogt, R. D. "An optimized density-based approach for extracting microplastics from soil and sediment samples", Environmental Pollution, 254, Article number: 113009, 2019. https://doi.org/10.1016/j.envpol.2019.113009

[71] Ghernaout, D. "The Best Available Technology of Water/ Wastewater Treatment and Seawater Desalination: Simulation of the Open Sky Seawater Distillation", Green and Sustainable Chemistry, 3(2), pp. 68-88, 2013. https://doi.org/10.4236/gsc.2013.32012

[72] Edo, C., González-Pleiter, M., Leganés, F., Fernández-Piñas, F., Rosal, R. "Fate of microplastics in wastewater treatment plants and their environmental dispersion with effluent and sludge", Environmental Pollution, 259, Article number: 113837, 2020. https://doi.org/10.1016/j.envpol.2019.113837

[73] Magni, S., Binelli, A., Pittura, L., Avio, C. G., Della Torre, C., Parenti, C. C., Gorbi, S., Regoli, F. "The fate of microplastics in an Italian Wastewater Treatment Plant", Science of The Total Environment, 652, pp. 602-610, 2019. https://doi.org/10.1016/j.scitotenv.2018.10.269

[74] Bayo, J., Olmos, S., López-Castellanos, J. "Microplastics in an urban wastewater treatment plant: The influence of physicochemical parameters and environmental factors", Chemosphere, 238, Article number: 124593, 2020. https://doi.org/10.1016/j.chemosphere.2019.124593

[75] Gurung, K., Ncibi, M. C., Fontmorin, J. M., Särkkä, H., Sillanpää, M. "Incorporating Submerged MBR in Conventional Activated Sludge Process for Municipal Wastewater Treatment: A Feasibility and Performance Assessment", Journal of Membrane Science \& Technology, 6(3), pp. 1-10, 2016. https://doi.org/10.4172/2155-9589.1000158

[76] He, H., Chen, Y., Li, X., Cheng, Y., Yang, C., Zeng, G. "Influence of salinity on microorganisms in activated sludge processes: A review", International Biodeterioration \& Biodegradation, 119, pp. 520-527, 2017. https://doi.org/10.1016/j.ibiod.2016.10.007

[77] Yang, L., Li, K., Cui, S., Kang, Y., An, L., Lei, K. "Removal of microplastics in municipal sewage from China's largest water reclamation plant", Water Research, 155, pp. 175-181, 2019. https://doi.org/10.1016/j.watres.2019.02.046

[78] Barrows, A. P. W., Christiansen, K. S., Bode, E. T., Hoellein, T. J. "A watershed-scale, citizen science approach to quantifying microplastic concentration in a mixed land-use river", Water Research, 147, pp. 382-392, 2018.

https://doi.org/10.1016/j.watres.2018.10.013
[79] Cincinelli, A., Scopetani, C., Chelazzi, D., Lombardini, E., Martellini, T., Katsoyiannis, A., Fossi, M. C., Corsolini, S. "Microplastic in the surface waters of the Ross Sea (Antarctica): Occurrence, distribution and characterization by FTIR", Chemosphere, 175, pp. 391-400, 2017. https://doi.org/10.1016/j.chemosphere.2017.02.024

[80] Cai, H., Chen, M., Chen, Q., Du, F., Liu, J., Shi, H. "Microplastic quantification affected by structure and pore size of filters", Chemosphere, 257, Article number: 127198, 2020. https://doi.org/10.1016/j.chemosphere.2020.127198

[81] da Costa Araújo, A. P., Silva de Melo, N. F., Goncalves de Oliveira Junior, A., Rodrigues, F. P., Fernandes, T., de Andrade Vieira, J. E., Rocha, T. L., Malafaia, G. "How much are microplastics harmful to the health of amphibians? A study with pristine polyethylene microplastics and Physalaemus cuvieri", Journal of Hazardous Materials, 382, Article number: 121066, 2020.

https://doi.org/10.1016/j.jhazmat.2019.121066

[82] Steer, M., Cole, M., Thompson, R. C., Lindeque, P. K. "Microplastic ingestion in fish larvae in the western English Channel", Environmental Pollution, 226, pp. 250-259, 2017. https://doi.org/10.1016/j.envpol.2017.03.062

[83] Masura, J., Baker, J. E., Foster, G. D., Arthur, C., Herring, C. "Laboratory Methods for the Analysis of Microplastics in the Marine Environment: Recommendations for quantifying synthetic particles in waters and sediments", [pdf] National Oceanic and Atmospheric Administration Marine Debris Division, Silver Spring, MD, USA, 2015. [online] Available at: https://marinedebris.noaa.gov/file/2538/download?token=b8VpceCY [Accessed: 07 July 2015]

[84] Fok, L., Lam, T. W. L., Li, H.-X., Xu, X. R. "A meta-analysis of methodologies adopted by microplastic studies in China", Science of The Total Environment, 718, Article number: 135371, 2020. https://doi.org/10.1016/j.scitotenv.2019.135371

[85] Hidalgo-Ruz, V., Gutow, L., Thompson, R. C., Thiel, M. "Microplastics in the Marine Environment: A Review of the Methods Used for Identification and Quantification", Environmental Science \& Technology, 46(6), pp. 3060-3075, 2012.

https://doi.org/10.1021/es2031505

[86] Olivatto, G. P., Martins, M. C. T., Montagner, C. C., Henry, T. B., Carreira, R. S. "Microplastic contamination in surface waters in Guanabara Bay, Rio de Janeiro, Brazil", Marine Pollution Bulletin, 139, pp. 157-162, 2019. https://doi.org/10.1016/j.marpolbul.2018.12.042

[87] Crawford, C. B., Quinn, B. "Microplastic separation techniques", In: Crawford, C. B., Quinn, B. Microplastic Pollutants, Elsevier, Amsterdam, Netherlands, 2017, pp. 203-218. https://doi.org/10.1016/B978-0-12-809406-8.00009-8

[88] Gimiliani, G. T., Fornari, M., Redígolo, M. M., Willian Vega Bustillos, J. O., Moledo de Souza Abessa, D., Faustino Pires, M. A. "Simple and cost-effective method for microplastic quantification in estuarine sediment: A case study of the Santos and São Vicente Estuarine System", Case Studies in Chemical and Environmental Engineering, 2, Article number: 100020, 2020. https://doi.org/10.1016/j.cscee.2020.100020 
[89] Fuller, S., Gautam, A. "A Procedure for Measuring Microplastics using Pressurized Fluid Extraction", Environmental Science \& Technology, 50(11), pp. 5774-5780, 2016. https://doi.org/10.1021/acs.est.6b00816

[90] Claessens, M., Van Cauwenberghe, L., Vandegehuchte, M. B., Janssen, C. R. "New techniques for the detection of microplastics in sediments and field collected organisms", Marine Pollution Bulletin, 70(1-2), pp. 227-233, 2013. https://doi.org/10.1016/j.marpolbul.2013.03.009

[91] Konechnaya, O., Lüchtrath, S., Dsikowitzky, L., Schwarzbauer, J. "Optimized microplastic analysis based on size fractionation, density separation and mu-FTIR", Water Science \& Technology, 81(4), pp. 834-844, 2020. https://doi.org/10.2166/wst.2020.173

[92] Stolte, A., Forster, S., Gerdts, G., Schubert, H. "Microplastic concentrations in beach sediments along the German Baltic coast", Marine Pollution Bulletin, 99(1-2), pp. 216-229, 2015. https://doi.org/10.1016/j.marpolbul.2015.07.022

[93] Pivokonsky, M., Cermakova, L., Novotna, K., Peer, P., Cajthaml, T., Janda, V. "Occurrence of microplastics in raw and treated drinking water", Science of The Total Environment, 643, pp. 1644-1651, 2018.

https://doi.org/10.1016/j.scitotenv.2018.08.102

[94] Xia, Y., Xiang, X. M., Dong, K. Y., Gong, Y. Y., Li, Z. J. "Surfactant stealth effect of microplastics in traditional coagulation process observed via 3-D fluorescence imaging", Science of The Total Environment, 729, Article number: 138783, 2020. https://doi.org/10.1016/j.scitotenv.2020.138783

[95] Lin, T., Yu, S., Chen, W. "Occurrence, removal and risk assessment of pharmaceutical and personal care products (PPCPs) in an advanced drinking water treatment plant (ADWTP) around Taihu Lake in China", Chemosphere, 152, pp. 1-9, 2016. https://doi.org/10.1016/j.chemosphere.2016.02.109

[96] Pivokonský, M., Pivokonská, L., Novotná, K., Čermáková, L., Klimtová, M. "Occurrence and fate of microplastics at two different drinking water treatment plants within a river catchment", Science of The Total Environment, 741, Article number: 140236, 2020. https://doi.org/10.1016/j.scitotenv.2020.140236

[97] Ma, B., Xue, W., Hu, C., Liu, H., Qu, J., Li, L. "Characteristics of microplastic removal via coagulation and ultrafiltration during drinking water treatment", Chemical Engineering Journal, 359, pp. 159-167, 2019 https://doi.org/10.1016/j.cej.2018.11.155

[98] Talvitie, J., Mikola, A., Koistinen, A., Setälä, O. "Solutions to microplastic pollution - Removal of microplastics from wastewater effluent with advanced wastewater treatment technologies", Water Research, 123, pp. 401-407, 2017. https://doi.org/10.1016/j.watres.2017.07.005

[99] Wang, R., Ji, M., Zhai, H., Liu, Y. "Occurrence of phthalate esters and microplastics in urban secondary effluents, receiving water bodies and reclaimed water treatment processes", Science of The Total Environment, 737, Article number: 140219, 2020. https://doi.org/10.1016/j.scitotenv.2020.140219
[100] Kim, S. W., An, Y. J. "A simple and efficient method for separation of low-density polyethylene films into different microsized groups for laboratory investigation", Science of the Total Environment, 668, pp. 84-89, 2019. https://doi.org/10.1016/j.scitotenv.2019.03.016

[101] Bannick, C. G., Szewzyk, R., Ricking, M., Schniegler, S., Obermaier, N., Barthel, A. K., Altmann, K., Eisentraut, P., Braun, U. "Development and testing of a fractionated filtration for sampling of microplastics in water", Water Research, 149, pp. 650-658, 2019. https://doi.org/10.1016/j.watres.2018.10.045

[102] Markiewicz, A., Strömvall, A. M., Björklund, K. "Alternative sorption filter materials effectively remove non-particulate organic pollutants from stormwater", Science of The Total Environment, 730, Article number: 139059, 2020 https://doi.org/10.1016/j.scitotenv.2020.139059

[103] Zhu, C., Kanaya, Y., Nakajima, R., Tsuchiya, M., Nomaki, H., Kitahashi, T., Fujikura, K. "Characterization of microplastics on filter substrates based on hyperspectral imaging: Laboratory assessments", Environmental Pollution, 263(B), Article number: 114296, 2020. https://doi.org/10.1016/j.envpol.2020.114296

[104] Baresel, C., Malmborg, J., Ek, M., Sehlén, R. "Removal of pharmaceutical residues using ozonation as intermediate process step at Linköping WWTP, Sweden", Water Science \& Technology, 73(8), pp. 2017-2024, 2016 https://doi.org/10.2166/wst.2016.045

[105] Ek, M., Baresel, C., Magnér, J., Bergström, R., Harding, M. "Activated carbon for the removal of pharmaceutical residues from treated wastewater", Water Science and Technology, 69(11), pp. 2372-2380, 2014 https://doi.org/10.2166/wst.2014.172

[106] Baresel, C., Harding, M., Fång, J. "Ultrafiltration/Granulated Active Carbon-Biofilter: Efficient Removal of a Broad Range of Micropollutants", Applied Sciences, 9(4), Article number: 710, 2019.

https://doi.org/10.3390/app9040710

[107] Grbic, J., Nguyen, B., Guo, E., You, J. B., Sinton, D., Rochman, C. M. "Magnetic Extraction of Microplastics from Environmental Samples", Environmental Science \& Technology Letters, 6(2), pp. 68-72, 2019. https://doi.org/10.1021/acs.estlett.8b00671

[108] Wang, L., Kaeppler, A., Fischer, D., Simmchen, J. "Photocatalytic $\mathrm{TiO}_{2}$ Micromotors for Removal of Microplastics and Suspended Matter", ACS Applied Materials \& Interfaces, 11(36), pp. 32937 32944,2019 https://doi.org/10.1021/acsami.9b06128

[109] Bayo, J., López-Castellanos, J., Olmos, S. "Membrane bioreactor and rapid sand filtration for the removal of microplastics in an urban wastewater treatment plant", Marine Pollution Bulletin, 156, Article number: 111211, 2020. https://doi.org/10.1016/j.marpolbul.2020.111211

[110] Miao, F., Liu, Y., Gao, M., Yu, X., Xiao, P., Wang, M., Wang, S., Wang, X. "Degradation of polyvinyl chloride microplastics via an electro-Fenton-like system with a $\mathrm{TiO}_{2} /$ graphite cathode", Journal of Hazardous Materials, 399, Article number: 123023, 2020. https://doi.org/10.1016/j.jhazmat.2020.123023 
[111] Tofa, T. S., Kunjali, K. L., Paul, S., Dutta, J. "Visible light photocatalytic degradation of microplastic residues with zinc oxide nanorods", Environmental Chemistry Letters, 17(3), pp. 1341-1346, 2019. https://doi.org/10.1007/s10311-019-00859-z

[112] Tofa, T. S., Ye, F., Kunjali, K. L., Dutta, J. "Enhanced Visible Light Photodegradation of Microplastic Fragments with Plasmonic Platinum/Zinc Oxide Nanorod Photocatalysts", Catalysts, 9(10), Article number: 819, 2019. https://doi.org/10.3390/cata19100819

[113] Auta, H. S., Emenike, C. U., Fauziah, S. H. "Screening of Bacillus strains isolated from mangrove ecosystems in Peninsular Malaysia for microplastic degradation", Environmental Pollution, 231(2), pp. 1552-1559, 2017. https://doi.org/10.1016/j.envpol.2017.09.043

[114] Dümichen, E., Eisentraut, P., Bannick, C. G., Barthel, A. K., Senz, R., Braun, U. "Fast identification of microplastics in complex environmental samples by a thermal degradation method", Chemosphere, 174, pp. 572-584, 2017. https://doi.org/10.1016/j.chemosphere.2017.02.010

[115] Gomiero, A., Øysæd, K. B., Agustsson, T., van Hoytema, N., van Thiel, T., Grati, F. "First record of characterization, concentration and distribution of microplastics in coastal sediments of an urban fjord in south west Norway using a thermal degradation method", Chemosphere, 227, pp. 705-714, 2019.

https://doi.org/10.1016/j.chemosphere.2019.04.096

[116] Leslie, H. A., Brandsma, S. H., van Velzen, M. J. M., Vethaak, A. D. "Microplastics en route: Field measurements in the Dutch river delta and Amsterdam canals, wastewater treatment plants, North Sea sediments and biota", Environment International, 101, pp. 133-142, 2017. https://doi.org/10.1016/j.envint.2017.01.018

[117] Mannina, G., Cosenza, A., Rebouças, T. F. "A plant-wide modelling comparison between membrane bioreactors and conventional activated sludge", Bioresource Technology, 297, Article number: 122401, 2020.

https://doi.org/10.1016/j.biortech.2019.122401

[118] Karapinar, N. "Magnetic separation of ferrihydrite from wastewater by magnetic seeding and high-gradient magnetic separation", International Journal of Mineral Processing, 71(1-4), pp. 45-54, 2003.

https://doi.org/10.1016/S0301-7516(03)00029-2

[119] Sun, M., Chen, W., Fan, X., Tian, C., Sun, L., Xie, H. "Cooperative recyclable magnetic microsubmarines for oil and microplastics removal from water", Applied Materials Today, 20, Article number: 100682, 2020.

https://doi.org/10.1016/j.apmt.2020.100682
[120] Kang, J., Zhou, L., Duan, X., Sun, H., Ao, Z., Wang, S. "Degradation of Cosmetic Microplastics via Functionalized Carbon Nanosprings", Matter, 1(3), pp. 745-758, 2019. https://doi.org/10.1016/j.matt.2019.06.004

[121] Ariza-Tarazona, M. C., Villarreal-Chiu, J. F., HernándezLópez, J. M., De la Rosa, J. R., Barbieri, V., Siligardi, C., CedilloGonzález, E. I. "Microplastic pollution reduction by a carbon and nitrogen-doped $\mathrm{TiO}_{2}$ : Effect of $\mathrm{pH}$ and temperature in the photocatalytic degradation process", Journal of Hazardous Materials, 395, Article number: 122632, 2020. https://doi.org/10.1016/j.jhazmat.2020.122632

[122] Nabi, I., Bacha, A. U. R., Li, K., Cheng, H., Wang, T., Liu, Y., ..., Zhang, L. "Complete Photocatalytic Mineralization of Microplastic on $\mathrm{TiO}_{2}$ Nanoparticle Film", iScience, 23(7), Article number: 101326, 2020. https://doi.org/10.1016/j.isci.2020.101326

[123] Debroas, D., Mone, A., Ter Halle, A. "Plastics in the North Atlantic garbage patch: A boat-microbe for hitchhikers and plastic degraders", Science of The Total Environment, 599-600, pp. 1222-1232, 2017.

https://doi.org/10.1016/j.scitotenv.2017.05.059

[124] Auta, H. S., Emenike, C. U., Jayanthi, B., Fauziah, S. H. "Growth kinetics and biodeterioration of polypropylene microplastics by Bacillus sp. and Rhodococcus sp. isolated from mangrove sediment", Marine Pollution Bulletin, 127, pp. 15-21, 2018. https://doi.org/10.1016/j.marpolbul.2017.11.036

[125] Li, R., Liu, Y., Sheng, Y., Xiang, Q., Zhou, Y., Cizdziel, J. V. "Effect of prothioconazole on the degradation of microplastics derived from mulching plastic film: Apparent change and interaction with heavy metals in soil", Environmental Pollution, 260, Article number: 113988, 2020. https://doi.org/10.1016/j.envpol.2020.113988

[126] Hsieh, Y. K., Hung, P. H., Huang, C. W., Chuang, K. C., Wang, J. "Study on the degradation of biodegradable poly (glycerol maleate) (PGM) microbeads", Polymer Degradation and Stability, 179, Article number: 109223, 2020. https://doi.org/10.1016/j.polymdegradstab.2020.109223

[127] Gupta, K. K., Devi, D. "Characteristics investigation on biofilm formation and biodegradation activities of Pseudomonas aeruginosa strain ISJ14 colonizing low density polyethylene (LDPE) surface", Heliyon, 6(7), Article number: e04398, 2020. https://doi.org/10.1016/j.heliyon.2020.e04398 